\title{
Studi Kasus Aliran Lumpur di Desa Pasir Panjang Menggunakan Program FLO-2D
}

\section{Case Study of Mudflow in Pasir Panjang Village by Using FLO-2D Program}

\author{
Budijanto Widjaja $^{1, a)}$ \& Dzaky Mahesa Wibowo ${ }^{1, b)}$ \\ 1)Jurusan Teknik Sipil, Fakultas Teknik, Universitas Katolik Parahyangan, Bandung. \\ Koresponden : ${ }^{a}$ widjaja@unpar.ac.id \& ${ }^{b)}$ 4114141@student.unpar.ac.id.
}

\begin{abstract}
ABSTRAK
Indonesia merupakan negara rawan bencana tanah longsor. Aliran lumpur (mudflow) merupakan salah satu jenis gerakan tanah yang dapat terjadi secara alamiah dan merupakan bencana alam geologi yang sering terjadi, salah satunya adalah pada bencana tanah longsor di Desa Pasir Panjang, Salem, Brebes. Mudflow merupakan salah satu tipe pergerakan tanah dalam kondisi jenuh air dengan dominan perilaku ditentukan oleh tanah butir halus. Tujuan dari penelitian ini adalah untuk memperoleh parameter tanah dari material longsoran di Desa Pasir Panjang, memperoleh parameter reologi berupa yield stress dan viskositas, dan mengetahui perilaku pergerakan tanah dengan menggunakan program FLO-2D. Untuk mencapai tujuan tersebut, dilakukan uji kadar air, uji berat jenis, uji Atterberg, uji hidrometer, uji saringan basah, uji fall cone penetrometer dan uji flow box. Sampel tanah yang digunakan terdiri dari 2 sampel, sampel 1 merupakan sumber area sedangkan sampel 2 merupakan deposisi area. Parameter tanah dan parameter reologi yang telah didapat digunakan pada program FLO-2D dengan 4 variasi liquidity index (LI) pada tiap sampel, yaitu 0.9, 1, 1.1, dan 1.2 . Dari hasil analisis, dapat disimpulkan bahwa semakin besar LI pada suatu sampel tanah, nilai viskositas dan nilai yield stress akan semakin kecil. Hasil simulasi numerik menunjukkan bahwa aliran lumpur ini dapat terjadi pada saat kadar air mencapai nilai batas cairnya.
\end{abstract}

Kata Kunci : manajemen aset infrastruktur, infrastruktur, evaluasi

\section{PENDAHULUAN}

Indonesia merupakan negara rawan bencana alam. Salah satu bencana alam yang sering terjadi di Indonesia adalah tanah longsor. Badan Nasional Penanggulangan Bencana mencatat bahwa sampai saat ini, Indonesia mengalami 2572 kejadian bencana pada tahun 2018, 473 diantaranya merupakan bencana tanah longsor (BNPB, 2019).

Lahan pada kasus tertentu harus dianggap sebagai bagian integral dari infrastruktur yang berada diatasnya. Hal ini menjadi sangat jelas pada kasus kelongsoran tanah, kasus likuifaksi akibat gempa dan kasus lain. Untuk keperluan Manajemen Aset Infrastruktur, baik pada tahap perencanaan, perancangan, pembangunan maupun pemakaian (Suprayitno \& Soemitro, 2018) karekteristik tanah perlu untuk diketahui dengan baik, guna merencanakan tindakan pencegahan tanah longsor.

Tanah longsor adalah suatu proses perpindahan massa tanah atau batuan dengan arah tegak, mendatar atau miring dari kedudukan semula, karena pengaruh gravitasi, arus air, dan beban luar (PUPR RI, 2002). Kondisi tanah yang jenuh air merupakan penyebab utama tanah longsor. Kondisi tersebut disebabkan oleh intensitas hujan yang tinggi, perubahan tingkat air 
tanah, dan perubahan permukaan air tanah. Peningkatan kadar air tanah dapat mempengaruhi kondisi tanah berupa aliran tanah. Parameter penting yang mengakibatkan kondisi aliran tanah hingga terjadinya longsor adalah viskositas $(\eta)$ dan yield stress $\left(\tau_{*}\right)$.

Tujuan penelitian ini adalah untuk memperoleh parameter tanah dari material longsoran di Desa Pasir Panjang, memperoleh parameter reologi berupa yield stress dan viskositas, dan mengetahui perilaku pergerakan tanah dengan menggunakan program FLO-2D. Longsor terjadi pada tanggal 22 Februari 2018 tepatnya pada pukul $08.45 \mathrm{WIB}$, yang menyebabkan 18 orang meninggal dunia, 4 orang hilang, dan belasan lainnya luka-luka. Peta lokasi gerakan tanah dapat dilihat pada Gambar 1.

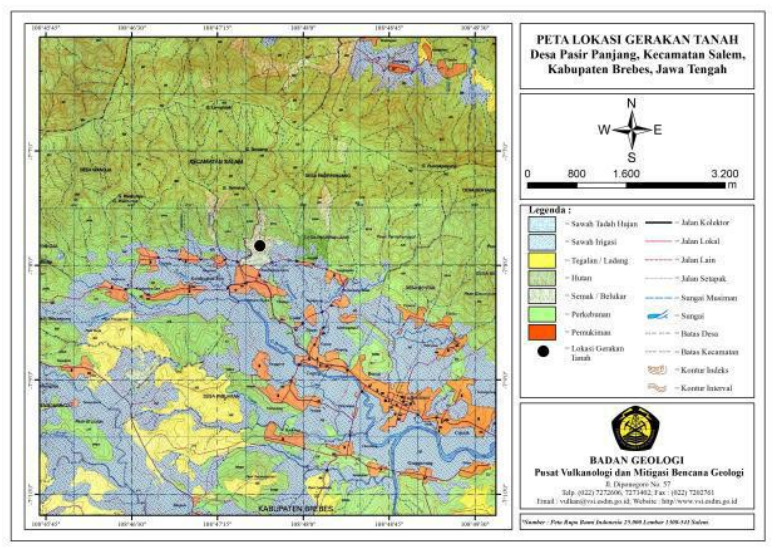

Gambar 1. Lokasi Gerakan Tanah Desa Pasir Panjang (ESDM, 2018)

\section{RUANG LINGKUP}

Penelitian ini mencakup beberapa hal yaitu untuk memperoleh parameter tanah dari material longsoran di Desa Pasir Panjang, memperoleh nilai kuat geser tanah (yield stress) dengan menggunakan uji fall cone penetrometer dan nilai viskositas dengan menggunakan uji flow box, mengetahui perilaku pergerakan tanah dengan menggunakan program FLO-2D, dan sampel tanah yang digunakan merupakan tanah terganggu (disturbed) yang diambil pada lokasi longsoran di Desa Pasir Panjang.

\section{METODE PENELITIAN}

Jenis longsor yang terjadi di Desa Pasir Panjang, Salem, Brebes merupakan jenis alir lumpur (mudflow). Menurut USGS (2004), mudflow adalah aliran bumi (earth flow) yang terdiri dari material yang cukup basah untuk mengalir dengan cepat dan mengandung setidaknya $50 \%$ partikel pasir, lumpur, dan tanah liat. Peningkatan kadar air pada tanah yang diakibatkan oleh meningkatnya intensitas hujan adalah salah satu penyebab terjadinya mudflow.

Mudflow sebagai cairan kental dapat dipahami menggunakan pendekatan reologi. Reologi didefinisikan sebagai studi tentang aliran dan deformasi. Ada dua parameter reologi yang dimiliki mudflow, yaitu yield stress dan viskositas. Yield stress merupakan parameter yang menentukan suatu aliran dapat terjadi. Sedangkan viskositas merupakan parameter yang menentukan kecepatan suatu aliran. Suatu material yang tidak memiliki yield stress disebut material Newtonian. Sedangkan material yang memiliki kedua parameter dikenal dengan material non-Newtonian, misalnya tanah (Widjaja, 2017).

Nilai yield stress ( $\tau$ ) pada penelitian ini dianggap sama besar dengan nilai kohesi $(\mathrm{cu})$. Hal ini dikarenakan tanah yang dominan pada penelitian ini merupakan tanah berbutir halus. Yield stress dapat dihitung menggunakan persamaan (1) (FLO-2D, 2007). 


$$
\tau_{y}=\alpha e^{\beta C_{v}}
$$

Dimana :

$$
\begin{aligned}
y & =\text { yield stress }(\mathrm{kPa}), \\
\alpha \text { dan } \beta & =\text { konstanta sebagai parameter input dalam FLO-2D, } \\
C_{v} & =\text { koefisien konsentrasi berdasarkan volume. }
\end{aligned}
$$

Nilai $C v$ dapat dicari menggunakan persamaan (2) untuk kasus tanah jenuh air.

$$
C_{v}=\frac{1}{1+G_{s} w}
$$

Dimana :

$$
\begin{array}{ll}
G_{s} & =\text { berat jenis } \\
W & =\text { kadar air } \\
C_{v} & =\text { koefisien konsentrasi berdasarkan volume. }
\end{array}
$$

Viskositas adalah sifat dasar dari semua cairan. Viskositas dapat disebut sebagai gaya hambatan dan merupakan ukuran sifat gesekan dari cairan (Viswanath et al., 2006). Jika nilai viskositas rendah maka aliran yang bergerak akan mengalir lebih cepat. Apabila nilai viskositasnya tinggi maka aliran akan mengalir lebih lambat (aliran semakin kental). Viskositas dapat dihitung menggunakan persamaan (3) (FLO-2D, 2007).

$$
\eta=\alpha e^{\beta C_{v}}
$$

Dimana :

$$
\begin{array}{ll}
\eta & =\text { viskositas }(\mathrm{Pa} \cdot \mathrm{s}), \\
\alpha \text { dan } \beta & =\text { konstanta sebagai parameter input dalam FLO-2D, } \\
C_{v} & =\text { koefisien konsentrasi berdasarkan volume. }
\end{array}
$$

Penelitian ini menggunakan metode studi literatur, studi lapangan, pengumpulan data dan uji laboratorium, dan analisis data dan simulasi. Studi literatur dilakukan dengan mempelajari buku, artikel, jurnal, dan referensi. Studi lapangan dilakukan dengan secara langsung datang ke lokasi longsor untuk mengetahui kondisi di lapangan, mencari informasi ke penduduk sekitar dan mengambil sampel tanah. Pada pengumpulan data dan uji laboratorium, data yang dikumpulkan pada penelitian ini berupa data topografi dan data karakteristik tanah. Data karakteristik tanah didapat melalui uji kadar air, uji berat jenis, uji batas-batas Atterberg, uji hidrometer, uji saringan basah, uji fall cone penetrometer dan uji flow box yang dilakukan di Laboratorium Geoteknik Universitas Katolik Parahyangan Bandung. Parameter karakteristik yang didapat melalui uji laboratorium akan digunakan pada analisis data dan simulasi menggunakan program FLO-2D untuk mengetahui perilaku pergerakan tanah.

FLO-2D atau Flood Routing Model merupakan software model konservasi volume sederhana yang mendistribusikan hidrograf melalui sistem elemen kotak persegi (grid). Program ini digunakan untuk mengetahui perilaku pergerakan tanah.

Pada simulasi program FLO-2D dibutuhkan parameter tanah dan parameter tambahan berupa nilai koefisien Manning ( $n$ ) dan parameter tahanan $K$. Nilai $n$ menunjukkan koefisien kekasaran tanah. Sedangkan nilai $K$ mempengaruhi kecepatan aliran dan area deposisi (d'Agostino dan Tecca, 2006). Parameter $K$ dan $n$ diambil berdasarkan kondisi permukaan sekitar longsoran di lapangan. Besarnya nilai $K$ dan $n$ dapat dilihat pada Tabel 1 dan Tabel 2 . 


Tabel 1. Nilai Parameter Tahanan (FLO-2D, 2007)
\begin{tabular}{cc}
\hline Surface & Range of K \\
\hline Concrete/asphalt & $24-108$ \\
Bare sand & $30-120$ \\
Graded surface & $90-400$ \\
Bare clay - loam soil, eroded & $100-500$ \\
Sparse vegetation & $1000-4000$ \\
\hline Short prairie grass & $3000-10000$ \\
\hline Bluegrass sod & $7000-50000$ \\
\hline
\end{tabular}

Nilai $K$ untuk kondisi permukaan di Desa Pasir Panjang berkisar antara 3000-10000 dan nilai $n$ berkisar antara 0.10-0.20. Kondisi permukaan di Desa Pasir Panjang merupakan short prairie grass. Pada penelitian ini nilai $n$ yang digunakan adalah 0.1 dan nilai $K$ yang digunakan adalah 3000 .

\section{PEMBAHASAN}

Sampel tanah yang digunakan pada penelitian ini diambil langsung di Desa Pasir Panjang. Terdapat dua sampel yang terdiri dari sampel di daerah mahkota (Sampel 1) dan sampel di daerah deposisi (Sampel 2).

Mahkota longsoran berada pada koordinat $108^{\circ} 47^{\prime} 19.68^{\prime \prime}$ BT ; $7^{\circ} 7^{\prime} 6.5856^{\prime \prime}$ LS. Lebar bidang longsor $140 \mathrm{~m}$, panjang bidang longsor $240 \mathrm{~m}$. Ketinggian lereng yang bergerak $108 \mathrm{~m}$, panjang $240 \mathrm{~m}$ sampai tekuk lereng dengan kemiringan antara $35^{\circ}$ pada bagian bawah lereng sampai lebih dari $45^{\circ}$ pada bagian atas. Landasan material mencapai $2.3 \mathrm{~km}$ dari mahkota longsor meliputi aliran sungai, kebun pinus, jalan, dan areal persawahan (ESDM, 2018).

Volume material mudflow yang berpindah diasumsikan sebesar $354,545.00 \mathrm{~m}^{3}$. Asumsi longsoran dengan ketebalan $4 \mathrm{~m}$ berdasarkan kondisi di lapangan. Luas area deposisi didapat menggunakan peta kontur sebesar $88,636.25 \mathrm{~m}^{2}$.

Berdasarkan uji laboratorium, didapatkan data karakteristik tanah di Desa Pasir Panjang. Hasil klasifikasi tanah pada sampel 1 dan sampel 2 berdasarkan Unified Soil Classification System (USCS) dapat dilihat pada Tabel 3 dan Gambar 2. Tanah pada sampel 1 dan sampel 2 merupakan tanah anorganik dengan tanah lanau plastisitas tinggi $(M H)$.

Uji fall cone penetrometer dilakukan untuk memperoleh kuat geser tanah dan uji flow box untuk memperoleh nilai viskositas. Pada penelitian ini nilai yield stress dan viskositas bergantung pada variasi nilai LI (liquidity index). Berdasarkan uji tersebut didapat nilai viskositas, yield stress dan berat isi tanah pada masing-masing LI. Parameter reologi Desa Pasir Panjang dapat dilihat pada Tabel 4.

Parameter reologi yang didapat, dibuat grafik hubungan viskositas dengan indeks kecairan $(L I)$ dengan grafik hubungan yield stress dan indeks kecairan $(L I)$. Melalui grafik tersebut dicari nilai viskositas dan yield stress saat $\mathrm{LI}=0.9, \mathrm{LI}=1, \mathrm{LI}=1.1$, dan $\mathrm{LI}=1.2$. Gambar 3 dan Gambar 4 merupakan grafik hubungan viskositas dan LI pada sampel 1 dan 2. Gambar 5 dan Gambar 6 merupakan hubungan yield stress dan LI pada sampel 1 dan 2. Nilai viskositas dan yield stress pada sampel 1 dan 2 dapat dilihat pada Tabel 5.

Pada program FLO-2D, perlu adanya 2 konstanta untuk memasukkan parameter reologi yang dapat dihitung menggunakan persamaan (1) dan persamaan (3). Nilai konstanta dan $C_{v}$ pada sampel 1 dan 2 yang akan digunakan pada program FLO-2D dapat dilihat pada Tabel 5 dan Tabel 6. 
Tabel 2. Nilai Koefisien Manning (FLO-2D, 2007)

\begin{tabular}{|c|c|c|}
\hline Surface & \multicolumn{2}{|c|}{ n-value } \\
\hline Dense turf & 0.17 & -0.8 \\
\hline $\begin{array}{l}\text { Bermuda and dense } \\
\text { grass, dense vegetation }\end{array}$ & 0.17 & -0.48 \\
\hline $\begin{array}{c}\text { Shrubs and forest litter, } \\
\text { pasture }\end{array}$ & 0.3 & -0.4 \\
\hline Average grass cover & 0.2 & -0.4 \\
\hline $\begin{array}{l}\text { Poor grass cover on } \\
\text { rough surface }\end{array}$ & 0.2 & -0.3 \\
\hline Short prairie grass & 0.1 & -0.2 \\
\hline Sparse vegetation & 0.05 & -0.13 \\
\hline \multicolumn{3}{|l|}{$\begin{array}{l}\text { Sparse rangeland with } \\
\text { debris }\end{array}$} \\
\hline $0 \%$ cover & 0.09 & -0.34 \\
\hline $20 \%$ cover & 0.05 & -0.25 \\
\hline \multicolumn{3}{|l|}{ Plowed or tilled fields } \\
\hline Fallow - no residue & 0.008 & -0.012 \\
\hline Conventional tillage & 0.06 & -0.22 \\
\hline Chisel plow & 0.06 & -0.16 \\
\hline Fall disking & 0.3 & -0.5 \\
\hline No till - no residue & 0.04 & -0.1 \\
\hline $\begin{array}{l}\text { No till }(20-40 \% \\
\text { residue cover })\end{array}$ & 0.07 & -0.17 \\
\hline $\begin{array}{l}\text { No till }(60-100 \% \\
\text { residue cover })\end{array}$ & & $0.17-0.4$ \\
\hline $\begin{array}{l}\text { Open ground with } \\
\text { debris }\end{array}$ & 0.1 & -0.2 \\
\hline $\begin{array}{l}\text { Shallow glow on } \\
\text { asphalt or concrete }\end{array}$ & 0.1 & -0.15 \\
\hline Fallow fields & 0.08 & -0.12 \\
\hline Open ground, no debris & 0.04 & -0.1 \\
\hline Asphalt or concrete & 0.02 & -0.05 \\
\hline
\end{tabular}

Tabel 3. Klasifikasi Tanah Desa Pasir Panjang

\begin{tabular}{ccccccc}
\hline Sampel & $\begin{array}{c}\text { Kadar air } \\
\text { w (\%) }\end{array}$ & $\begin{array}{c}\text { Batas cair } \\
\text { LL }\end{array}$ & $\begin{array}{c}\text { Batas Plastis } \\
\text { PL }\end{array}$ & $\begin{array}{c}\text { Batas Cair Oven } \\
\text { LL } \text { Oven }^{2}\end{array}$ & $\begin{array}{c}\text { Berat jenis } \\
\mathrm{G}_{\mathrm{s}}\end{array}$ & USCS \\
\hline 1 & 9.6 & 91.55 & 52.52 & 79.28 & 2.65 & $\mathrm{MH}$ \\
\hline 2 & 24.9 & 52.32 & 38.41 & 48.94 & 2.62 & $\mathrm{MH}$ \\
\hline
\end{tabular}




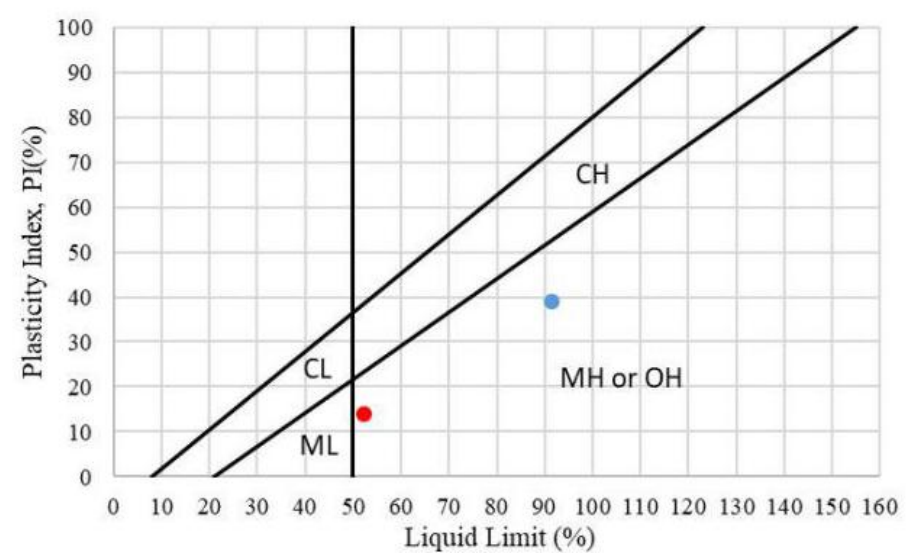

Gambar 2. Klasifikasi Tanah Desa Pasir Panjang

Tabel 4. Parameter Reologi Desa Pasir Panjang

\begin{tabular}{cccccccc}
\hline $\begin{array}{c}\text { Sampel } \\
\text { No }\end{array}$ & $\begin{array}{c}\text { Batas } \\
\text { Cair } \\
\text { LL }\end{array}$ & $\begin{array}{c}\text { Batas } \\
\text { Plastis } \\
\text { PL }\end{array}$ & $\begin{array}{c}\text { Indeks } \\
\text { Kecairan } \\
\text { LI }\end{array}$ & $\begin{array}{c}\text { Kadar air } \\
\mathbf{w}(\%)\end{array}$ & $\begin{array}{c}\text { Viskositas } \\
\boldsymbol{\eta}(\mathbf{P a} \cdot \mathbf{s})\end{array}$ & $\begin{array}{c}\text { Yield } \\
\text { stress } \\
\boldsymbol{\tau}_{\mathbf{y}}(\mathbf{k P a})\end{array}$ & $\begin{array}{c}\text { Berat isi } \\
\boldsymbol{\gamma}\left(\mathbf{k N} / \mathbf{m}^{\mathbf{3}}\right)\end{array}$ \\
\hline & & & 0.84 & 85 & 2.4 & 3.515 & 16.15 \\
& & & 0.93 & 89 & 0.88 & 2.941 & 16.05 \\
\multirow{2}{*}{1} & \multirow{2}{*}{91.549} & 52.524 & 1.05 & 94 & 0.25 & 2.106 & 15.65 \\
& & & 1.13 & 97 & 0.115 & 1.906 & 15.52 \\
& & & 1.24 & 101 & 0.055 & 1.669 & 14.48 \\
\hline & & & 0.74 & 49 & 20 & 7.861 & 17.26 \\
& & & 0.9 & 51 & 9 & 6.884 & 17.24 \\
2 & \multirow{2}{*}{52.323} & 38.41 & 1.04 & 53 & 5 & 6.287 & 16.99 \\
& & & 1.19 & 55 & 3.5 & 4.473 & 16.54 \\
& & & 1.32 & 57 & 2.8 & 4.1 & 16.13 \\
\hline
\end{tabular}

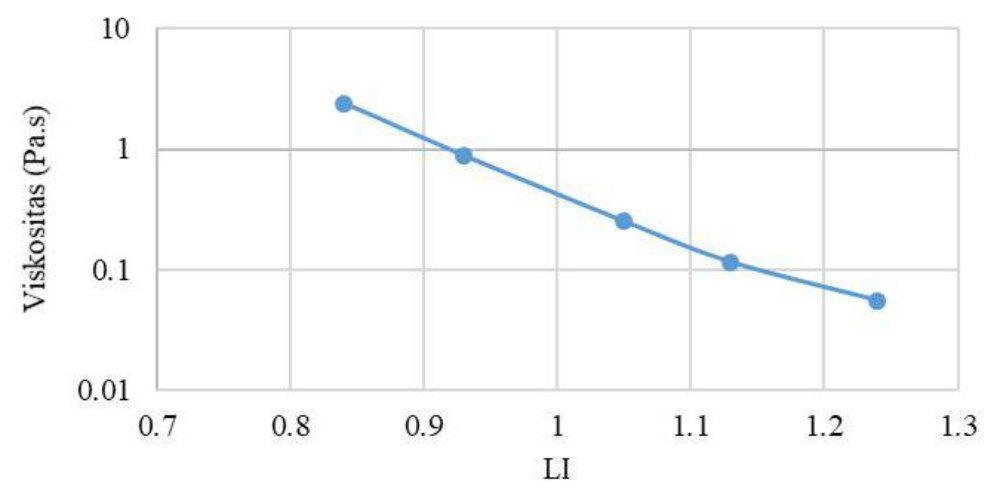

Gambar 3. Hubungan Viskositas dan LI pada Sampel 1 


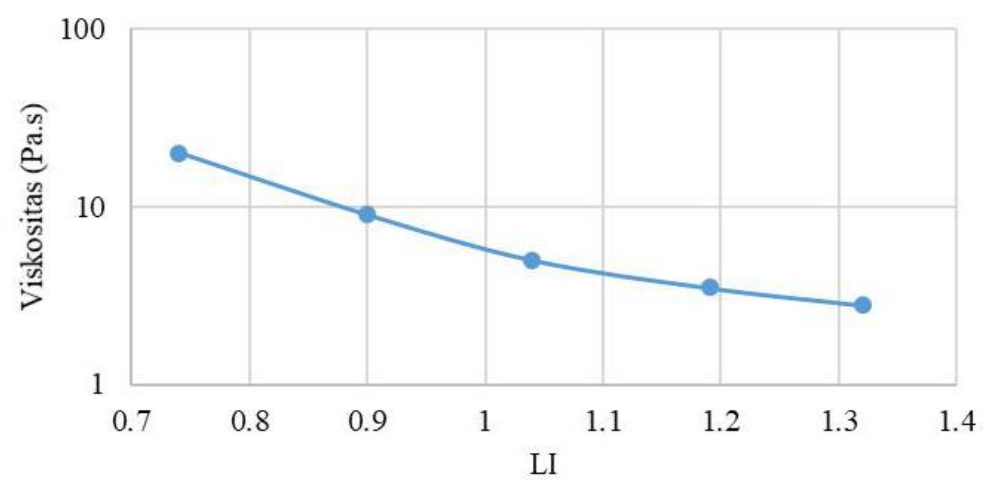

Gambar 4. Hubungan Viskositas dan LI pada Sampel 2

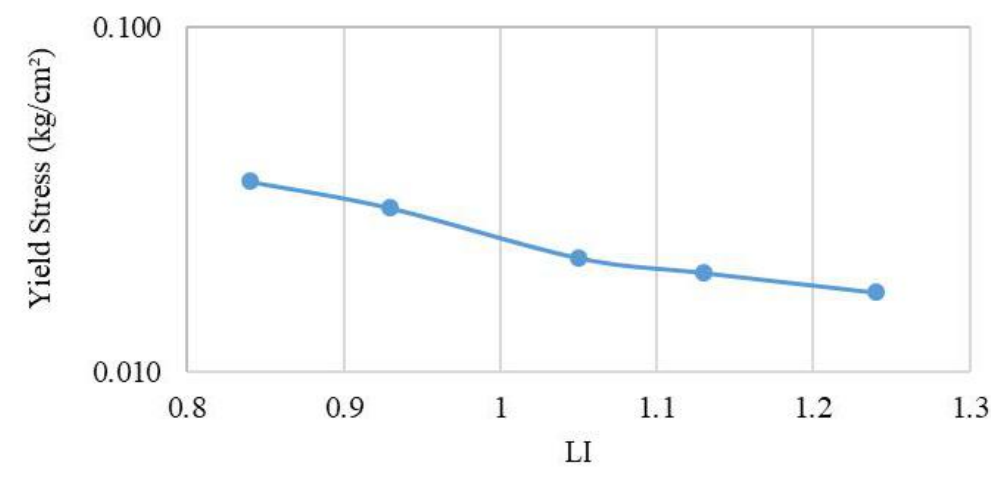

Gambar 5. Hubungan Yield Stress dan LI pada Sampel 1

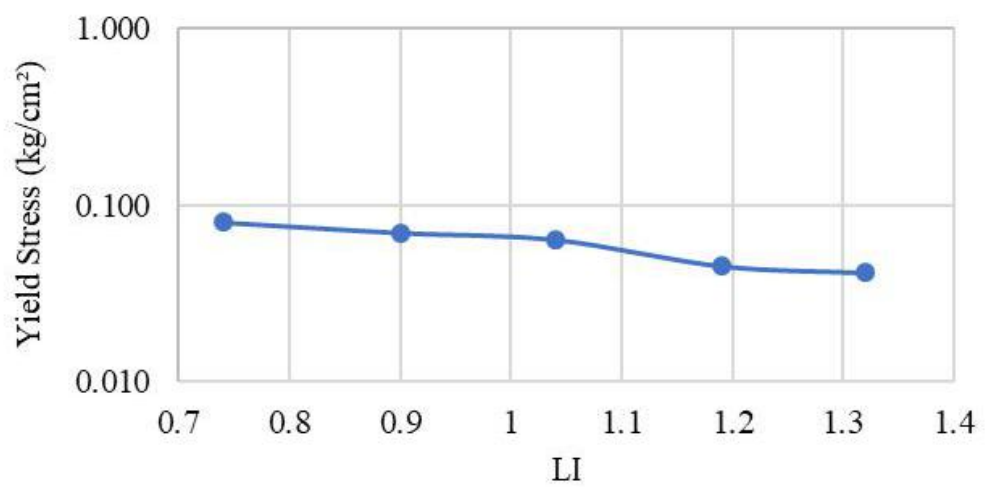

Gambar 6. Hubungan Yield Stress dan LI pada Sampel 2

Tabel 5. Nilai Viskositas dan Yield Stress pada Sampel 1 dan 2

\begin{tabular}{ccccc}
\hline & \multicolumn{2}{c}{ Sampel 1 } & \multicolumn{2}{c}{ Sampel 2 } \\
\hline LI & $\boldsymbol{\eta}$ & $\boldsymbol{\tau}_{\boldsymbol{y}}$ & $\boldsymbol{\eta}$ & $\boldsymbol{\tau}_{\boldsymbol{y}}$ \\
& $(\mathbf{P a} \cdot \mathbf{s})$ & $(\mathbf{P a})$ & $(\mathbf{P a} \cdot \mathbf{s})$ & $(\mathbf{k P a})$ \\
\hline 0.9 & 1.387 & 3.132 & 9 & 6.884 \\
\hline 1 & 0.513 & 2.454 & 6.143 & 6.458 \\
\hline 1.1 & 0.166 & 1.981 & 4.4 & 5.562 \\
\hline 1.2 & 0.077 & 1.755 & 3.446 & 4.444 \\
\hline
\end{tabular}


Tabel 6. Nilai Konstanta FLO-2D dan $C_{v}$ pada Sampel 1

\begin{tabular}{ccccccc}
\hline $\mathbf{L I}$ & $\boldsymbol{C}_{\boldsymbol{v}}$ & $\begin{array}{c}\boldsymbol{\tau} \\
(\mathbf{P a} \cdot \mathbf{s})\end{array}$ & $\begin{array}{c}\boldsymbol{\tau}_{\boldsymbol{y}} \\
(\mathbf{k P a})\end{array}$ & $\boldsymbol{\alpha}$ & $\boldsymbol{\beta}_{\boldsymbol{\eta}}$ & $\boldsymbol{\beta}_{\tau_{\mathrm{y}}}$ \\
\hline 0.9 & 0.301 & 1.387 & 3.132 & 0.1 & 16.867 & 42.042 \\
\hline 1 & 0.292 & 0.513 & 2.454 & 0.1 & 13.482 & 42.502 \\
\hline 1.1 & 0.283 & 0.166 & 1.981 & 0.1 & 9.919 & 43.097 \\
\hline 1.2 & 0.275 & 0.077 & 1.755 & 0.1 & 7.413 & 43.91 \\
\hline
\end{tabular}

Tabel 7. Nilai Konstanta FLO-2D dan $C_{v}$ pada Sampel 2

\begin{tabular}{ccccccc}
\hline $\mathbf{L I}$ & $\mathbf{C}_{\mathbf{v}}$ & $\begin{array}{c}\boldsymbol{\eta} \\
(\mathbf{P a} \cdot \mathbf{s})\end{array}$ & $\begin{array}{c}\boldsymbol{\tau}_{\mathrm{y}} \\
(\mathbf{k P a})\end{array}$ & $\boldsymbol{\alpha}$ & $\boldsymbol{\beta}_{\boldsymbol{\eta}}$ & $\boldsymbol{\beta}_{\boldsymbol{\tau}_{\boldsymbol{v}}}$ \\
\hline 0.9 & 0.428 & 9 & 6.884 & 0.1 & 15.894 & 31.407 \\
\hline 1 & 0.422 & 6.143 & 6.458 & 0.1 & 15.214 & 31.702 \\
\hline 1.1 & 0.415 & 4.4 & 5.562 & 0.1 & 14.667 & 31.877 \\
\hline 1.2 & 0.409 & 3.446 & 4.444 & 0.1 & 14.285 & 31.796 \\
\hline
\end{tabular}

Hidrograf untuk kasus mudflow Desa Pasir Panjang dibuat berdasarkan besar volume area deposisi 354,5 $\mathrm{m}^{3}$. Durasi perpindahan mudflow dari source area hinga berhenti di area deposisi diperkirakan selama 15 menit, dan didapatkan besar debit aliran sebesar $393.9 \mathrm{~m}^{3} /$ detik menggunakan persamaan (4). Hidrograf untuk Simulasi program FLO-2D dapat dilihat pada Gambar 7.

$$
Q=\frac{V}{t}
$$

$$
\begin{aligned}
\text { Dimana : } & \\
Q & =\text { debit }\left(\mathrm{m}^{3} / \text { detik }\right) \\
V & =\text { volume }\left(\mathrm{m}^{3}\right) \\
t & =\text { waktu (detik) }
\end{aligned}
$$

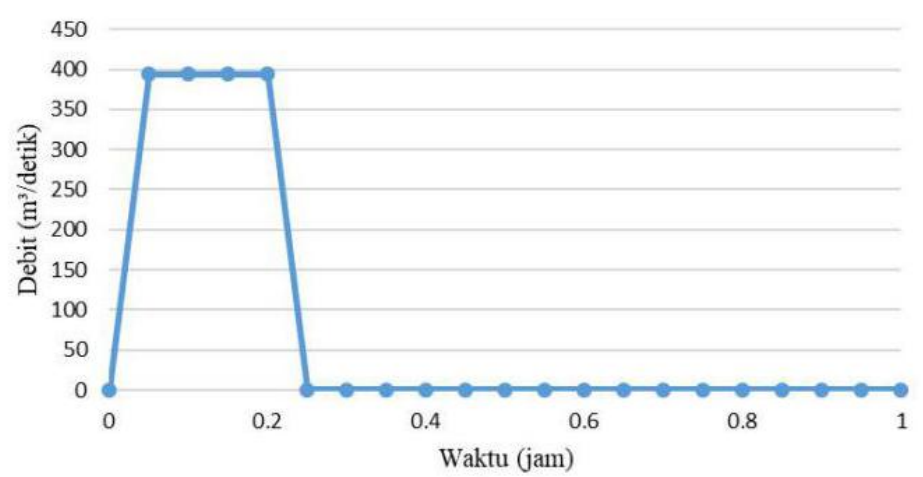

Gambar 7. Hidrograf untuk Simulasi program FLO-2D

Berdasarkan analisis menggunakan program FLO-2D, hasil kecepatan maksimum dan kedalaman maksimum dapat dilihat pada Tabel 7. Pada penelitian ini terdapat 8 skenario yang terdiri dari 4 skenario menggunakan sampel 1 dan 4 skenario menggunakan sampel 2 . 
Tabel 7. Hasil Program FLO-2D

\begin{tabular}{ccccc}
\hline \multirow{2}{*}{ Sampel } & Skenario & LI & $\begin{array}{c}\text { Kecepatan } \\
\text { Maksimum } \\
(\mathbf{m} / \mathbf{s})\end{array}$ & $\begin{array}{c}\text { Kedalaman } \\
\text { Maksimum } \\
(\mathbf{m})\end{array}$ \\
\hline & 1 & 0.9 & 10.5 & 9.4 \\
\cline { 2 - 5 } 1 & 2 & 1 & 10.9 & 8.6 \\
\cline { 2 - 5 } & 3 & 1.1 & 11 & 8.2 \\
\hline & 4 & 1.2 & 10.9 & 8 \\
\hline & 5 & 0.9 & 10.8 & 12.9 \\
\hline & 6 & 1 & 11.1 & 12.4 \\
\hline & 7 & 1.1 & 11.2 & 11.6 \\
\hline & 8 & 1.2 & 11.2 & 10.7 \\
\hline
\end{tabular}

\section{KESIMPULAN}

Tanah longsoran di Desa Pasir Panjang diklasifikasikan sebagai silt with high plasticity $(M H)$. Nilai viskositas di Desa Pasir Panjang pada sampel 1 berkisar antara 1.387 Pa $\bullet$ sampai dengan $0.077 \mathrm{~Pa} \bullet$ s, sedangkan pada sampel 2 berkisar antara $9 \mathrm{~Pa} \bullet$ s sampai dengan $3.446 \mathrm{~Pa} \bullet \mathrm{s}$. Nilai yield stress di Desa Pasir Panjang pada sampel 1 berkisar antara $1.75 \mathrm{kPa}$ sampai dengan $3.13 \mathrm{kPa}$, sedangkan pada sampel 2 berkisar antara $4.44 \mathrm{kPa}$ sampai dengan $6.88 \mathrm{kPa}$. Nilai yield stress ini cukup dekat dengan variasi nilai kohesi pada saat kadar air sebesar batas cairnya.

Dari 8 skenario perubahan indeks kecairan untuk kasus Desa Pasir Panjang, diperoleh bahwa kecepatan maksimum longsoran ini cukup konsisten yakni berkisar antara $10.5-11.2$ $\mathrm{m} / \mathrm{s}$. Adapun kedalaman material pada daerah deposisi bervariasi dari $8-12.9 \mathrm{~m}$ tergantung pada variasi kadar air materi longsoran.

\section{DAFTAR PUSTAKA}

Arora, K. R. (2003). Soil Mechanics and Foundation Engineering. Lomus. Delhi.

Barnes, H. A. (2000). A Handbook of Elementary Rheology. Institute of Non-Newtonian Fluid Mechanics. University of Wales. Aberystwyt.

BNPB (2019). Data Informasi Bencana Indonesia. http://bnpb.cloud/dibi/laporan5. (diakses tanggal 11 Februari 2019)

D’Agostino, V. \& Tecca, P.R. (2006). "Some Considerations On The Application Of The FLO-2D Model For Debris Flow Hazard Assessment, (Monitoring, Simulation, Prevention and Remediation of Dense and Debris Flows"). 160-170.

Das, B. M. (1995). Mekanika Tanah (Prinsip-prinsip Rekayasa Geoteknis). Erlangga. Jakarta. PUPR (2002). “Metode, Spesifikasi dan Tata Cara Bagian I: Tanah Longsor". Departemen Permukiman dan Prasarana Wilayah. Jakarta.

Dikau, R., Brunsden, D., Lthar, S. \& Ibsen, M.L. (1996). Landslide Recognition: Identification Movement and Causes. John Wiley \& Sons. Chicester.

ESDM (2018). (Laporan Singkat Pemeriksaan Gerakan Tanah Di Kecamatan Salem, Kab. Brebes Provinsi Jawa Tengah). http://www.vsi.esdm.go.id/index.php/gerakan- 
tanah/kejadian-gerakan-tanah/1971-laporan-singkat-pemeriksaan-gerakan-tanah-dikecamatan- salem-kab-brebes-provinsi-jawa-tengah. (diakses tanggal 11 Februari 2019).

Suprayitno, H. \& Soemitro, R.A.A. (2018)."Preliminary Reflexion on Basic Principle of Infrastructure Asset Management". Jurnal Manajemen Aset Infrastruktur \& Fasilitas, Vol.2, No.1, Maret 2018, Hal : 1-9.

USGS (2004). Landslide Types and Processes. United States Geological Survey. https://pubs.usgs.gov/fs/2004/3072/fs-2004- 3072. html. (diakses tanggal 11 Februari 2019) .

Varnes, D.J. (1978) Slope Movement Types and Processes. Transportation Research Board, Special Report, 11-33.

Varnes, D.J., \& Cruden, D.M. (1993). Landslide Type and Processes. Investigation and Mitigation, 1-60. Landslide.

Viswanath, D.S., Ghosh, T.K., Prasad, D.H.L., Dutt, N.V.L., \& Rani, K. (2006). Viscosity of Liquids, Springer, Dordrecht.

Widjaja, B. (2017). "Perilaku Longsoran dan Mudflow Studi Kasus di Indonesia : Pendekatan Reologi”. Simposium Nasional RAPI XVI, 145-151.

Widjaja, B. \& Lee, S.H. (2013). "Flow Box Test for Viscosity of Soil in Plastic and Viscous Liquid States". Soils and Foundation, 35-46.

Widjaja, B., \& Yovita, N. (2013). "Penentuan Viskositas dan Yield Stress dengan Flow Box Test untuk Mudflow". Conference Paper, 325-330.

Widjaja, B., Naikofi, M. I., \& Rahardjo, P.P. (2017). "Studi Reologi Mud Volcano di Desa Napan Pulau Timor dengan Flow Box Test". Conference Paper, 1-7.

Widjaja, B., Rahardjo, P.P., Putri, A.R., Setiabudi, D.W., \& Octora, I. (2014). Perbandingan Yield Stress dan Viskositas Menggunakan Van Shear dan Flow Box Test untuk Menjelaskan Perilaku Mudflow. Universitas Katolik Parahyangan, 1-110. 